\title{
The Acquisition and use of negation in the early child language
}

\author{
Vildan İnci Kavak a * (iD) \\ ${ }^{a}$ Gaziantep University, School of Foreign Languages, Gaziantep, Turkey
}

\section{APA Citation:}

İnci Kavak, V.(2019). The acquisition and use of negation in the early child language. Journal of Language and Linguistic Studies, 15(2), 587604.

Submission Date: 15/11/2018

Acceptance Date: 23/01/2019

\begin{abstract}
This paper investigates how negation develops in the speech of a Turkish-speaking child in the very early stages of language acquisition. The study features the video recordings of a child between the ages of 19 and 22 months and the analyses of negative forms in the recorded data. The development of negation in parent-child interactions is discussed with demonstrative examples between the boy and his parents. The data was recorded by the mother in a regular fashion, particularly at play and lunch times. For the detailed data analysis, the recordings have been divided into three sets according to the age of the child as $1 ; 8,1 ; 9$ and $1 ; 10$. The initial step is to identify and explain how negation is formed in Turkish, which is followed by the data analysis in order to track the development of negation in the child's speech. The ways in which his formation of negation improves have been given special attention and interpreted as the child's linguistic knowledge expands. The data evidences that the child not only starts to use most forms of negation as early as the age of $1 ; 10$, but also does this strategically by performing them for a successful communication in a clear developmental sequence. Some of his strategies traced in the data are using variety sets, complementing one negative form with the other to emphasize his point and providing reasons and results for his statements. The findings confirm that the child acquires the forms in an order from more independent to the dependent as well as in a sequence from the easy to the linguistically and cognitively more challenging.
\end{abstract}

(C) 2019 JLLS and the Authors - Published by JLLS.

Keywords: Child language; Turkish language acquisition; negative forms; development of negation.

\section{Introduction}

All human systems of communication possess a representation of negation in language to enable speakers to express themselves for communicative purposes. Horn (1989) identifies the most frequent purposes as assigning the truth value for lying, irony, or coping with false or contradictory statements. A number of studies have investigated the issue of negation in languages and researchers have mostly focused on its developmental stages, forms (Klima \& Bellugi, 1966; Bellugi, 1967) and functional aspects (Vaidyanathan, 1991, de Villiers \& de Villiers, 1979) as well as linguistic dimensions (Bloom, 1970; McNeill \& McNeill, 1973; de Villiers \& de Villiers, 1979). However, there is a limited number of studies in Turkish and the available research in different languages fails to elucidate the specifics and

\footnotetext{
${ }^{*}$ Corresponding author. Tel.: +0 3423172936

E-mail address: vildan_elt@hotmail.com
} 
idiosyncrasies of the acquisition of negation in Turkish. An important point is that not only child's spontaneous speech but also the interaction between parent and child should be taken into consideration as parents' speech is fundamental in the development of child's speech functioning as both an input and model for production.

Negation is a vital form for a child to manage communication even at the very early stages. Negative forms also provide rich data for researchers and provide useful information about the language system, which is claimed to be acquired early in many languages (Krashen, 1981). Thus, this study will attempt to contribute to the literature on the developmental sequences of negation by children, in the particular case, by a native speaker of Turkish, which will help deepen our understanding of L1 (first language) acquisition processes.

In this article, negation structures that are found in the speech of a Turkish child (from approximately 19 to 22 months) are investigated. It is observed that there is considerable growth in the speech of the child in terms of the use of negatives over a three-month period. At some stages, he abruptly starts to produce certain negative constructions and combination of these constructions, which have not been available in the data earlier. This encourages us to look for the strategies he uses, which corresponds to the reflection of his expanded knowledge in negation. In the light of these, the study makes an attempt to trace the development of negative forms by a Turkish child in a longitudinal study, identify what strategies the child uses to expand his production of negation and increase the complexity and compare the results of this study with those of previous research.

To do this, the paper is organised in the following way: Section 2 provides a brief description of Turkish grammar and the means and forms of negation in Turkish. Section 3 gives a detailed explanation of the changes in the form of negation found in the data. The conclusion summarizes the study and presents implications for further studies.

\section{Turkish Grammar}

A brief explanation on Turkish grammar is presented in this section in order to give useful information about the nature of the language, which will help the interpretation of the data analysed in the Results section. As "an Altaic language with the features of an object-verb language" (Greenberg, 1966; Lehman, 1978; Aksu-Koc \& Slobin, 1985), "the basic word order in Turkish is 'Subject-objectverb' (SOV), with suffixed inflections, postpositions, preposed demonstratives, numerals, possessives, adjectives, and relative clauses" (Erguvanl1, 1979; Aksu-Koc \& Slobin, 1985).

Having a highly agglutinating nature, Turkish morphemes work as a link in the chain by positioning in the string with their phonological and semantic features. Each morph is syllabic and the stress is positioned in the word-final position. As mentioned in Aksu-Koc \& Slobin (1985), the order of noun suffixes is: stem + (plural) + (possessive $)+($ case $)$. The possible combinations are exemplified below in Table 1:

Table 1. The possible combinations of noun suffixes

\begin{tabular}{|l|l|l|l|}
\hline Singular & English & Plural & English \\
\hline $\begin{array}{l}\text { okul } \\
\text { school (stem) }\end{array}$ & school & $\begin{array}{l}\text { okul-lar } \\
\text { school PLU }\end{array}$ & schools \\
\hline $\begin{array}{l}\text { Okul-um } \\
\text { school POSS }\end{array}$ & my school & $\begin{array}{l}\text { okul-lar-1m } \\
\text { school PLU POSS }\end{array}$ & my schools \\
\hline $\begin{array}{l}\text { Okul-da } \\
\text { school LOC }\end{array}$ & at school & $\begin{array}{l}\text { okul-lar-da } \\
\text { school PLU LOC }\end{array}$ & at schools \\
\hline
\end{tabular}




\begin{tabular}{|l|l|l|l|}
\hline $\begin{array}{l}\text { Okul-um-da } \\
\text { School POSS LOC }\end{array}$ & at my school & $\begin{array}{l}\text { okul-lar-1m-da } \\
\text { school PLU POSS LOC }\end{array}$ & at my schools \\
\hline
\end{tabular}

Moreover, verbs are also agglutinated in Turkish. By affixation, which is adding suffixes to the stem, verbs mark tense/aspect, modality, negation, number and person in order. As Aksu-Koç notes that

"The tense/aspect suffixes are present progressive (-Iyor), aorist (-Ir), reported past (-mIş), future ((y)AcAK) and definite past (-DI) that can be applied to the verb roots with proper phonological variants depending on the vowel and consonant harmony rules. Modality is also marked with the neccessitative (-mAlI), abilitative (-(y)AbIl), potential ((y)AbIl), and conditional (-sA) suffixes, person suffixes mark the subject-verb agreement" (1988, p.17).

\subsection{Negative Forms in Turkish}

There are four means of negation in Turkish. These are $\imath h$ hlh, yok, değil and $-m A$. Ih-hlh (and also $c l k$ ) is a universal negative marker, which can be applied to all types of predication after the model for negation of nonverbal predicates. Yok ('no') is used to express nonexistentiality. In other words, it is the negation of var 'existent' (Goksel \& Kerslake, 2005):

Kalem-im yok.

'My pencil is not here (existent).'

Pencil- POS NEG: EXIS

Değil ('not') is mostly used to make nonverbal sentences (Underhill, 1976). The person suffix generally follows it as in the example:

Ben doktor değil-im. ' 'I am not a doctor.'

I doctor not $1 \mathrm{SG}$

"Değil can also be used to make verbal sentences. In this case, the verb is typically conjugated with the imperfective marker -Iyor, less commonly with the future marker -(y)AcAK or the perfective marker mIş" (Göksel, Kerslake, 2005):

Her gün ders çalış-1yor değil-im. 'It's not the case that I study every day.' study-IMPF not-1SG

Another form of negation is made by inserting the suffix $-m A$ ( $-A$ is in capitals as it harmonizes with the last vowel of the verb stem, and can possibly turn into $-\mathrm{e},-1,-\mathrm{i},-\mathrm{u}$ and -ü.). It is located after the verb stem and before the modal, tense and person suffixes (Underhill, 1976):

git-me-(y)eceğ-(i)m 'I won't go.'

(go-NEG- FUT-1SG)

However, "there are some irregularities in the combination of the negative marker with the aorist -(A/I)r (producing the combination -mA-z) and the possibility suffix -(y)A" (Goksel \&Kerslake, 2005):

$\begin{array}{llll}\text { ye-r } & \text { (come-AOR-3SG) } & \text { ye-me-z } & \text { (come-NEG-3SG) } \\ \text { gör-ebil-di } & (\text { see-ABIL-PAST-3SG) } & \text { gör-e-me-di } & \text { (see-ABIL-NEG-PAST) }\end{array}$




\subsection{Simplification of Negation in Child's Speech}

All children usually simplify the system of negation. When they have acquired a form of negation they tend to apply it to every predication so they overgeneralize the rule whether it is a noun or a verb (Aksu-Koç, Slobin, 1985). As it is clear in the examples below, young speakers consistently use the word yok (Example a), değil (Example b), gitti (Example c), which function as amalgam words to state the nonexistence, thus they have the same meaning with yok. Alternatively, speakers simply use $\imath h \mathrm{~h} h \mathrm{~h}$ (Example d) to express negation by preserving the main sentences without making morphophonemic changes to them which would be needed for the correct versions (Aksu-Koç, Slobin, 1985, p.304):
a. Ay, koy-du-m yok
I didn't put it

Oh put PAST 1SG NEG

Intended meaning: koy-ma-d1-m (put-NEG-PAST-1SG)

b. Anne otur, kalk değil.

Mother sit, don't get up.

Mother sit get up NEG

Intended meaning: kalk-ma (get up- NEG)

c. Baba gitti.

Daddy has gone.

Daddy gone.

Intended meaning: Daddy isn't existent

d. Yap-1cağ-1m $1 \mathrm{~h}$. I won't do (it).

Do FUT 1SG NEG

Intended: yap-ma-yacağ-1m(do-NEG-FUT-1SG)

In addition, Turkish children begin to use nearly all the verb paradigms before the age of 2 (AksuKoc \& Slobin, 1985) as the negative forms in Turkish can be acquired earlier in comparison to English. Turkish children do not have to deal with different forms of auxiliary verbs such as am, is, are, do, does, did, have, has etc. to be able to produce accurate sentences. In Turkish, children can negate verb predicates only by inserting the negative particle $-m A$ - after the verb stem. For example, ver-di-m (givePAST-1SG) and ver-me-di-m (give- NEG-PAST-1SG).

\section{Methodology}

\subsection{Participants}

The data have been obtained from the recordings of a Turkish-speaking child. The recordings mainly include mother-child interactions. The boy named Yusuf Ata is the only child of the couple who are both graduates. His father is the holder of a PhD in ELT and works as a lecturer at a state university in Turkey. His mother is a BA graduate of French Translation and continues her studies in ELT. They frequently travel in their free times, so the child has already had the experience of visiting the UK and Macedonia at an early age. Therefore, the household provide rich and systematic linguistic and social input for the child. Turkish is the main language spoken by the household, but both parents also expose their child to English as much as possible as a second language, so they have casual dialogues, offer some games and encourage him to watch videos in English.

\subsection{Recordings}

Regarding the data, the parents were asked to interact with the child during the recordings as normal. The mother recorded the child every week for about 20 to 30 minutes for about 3 months between the ages of $1 ; 8$ and $1 ; 10$ in three slots $(1 ; 8,1 ; 9$ and $1 ; 10)$. The videos were taken at home while the parents were caretaking and doing free activities (feeding, dressing, playing etc.). The videos comprised the 
speech with the child and his own speech. Comments were made note of on the context in which expressions and statements were produced. Home visits were also arranged to be able to observe the child in person and discover the setting of the videos.

\section{Results and Discussion}

Table 2. The percentage of child utterance

\begin{tabular}{ccccc}
\hline Sets & Age & Total Utterance & Child Utterance & Percent \\
\hline Set 1 & $1 ; 8$ & 1140 & 381 & $33 \%$ \\
Set 2 & $1 ; 9$ & 1350 & 494 & $36 \%$ \\
Set 3 & $1 ; 10$ & 1574 & 676 & $75 \%$ \\
\hline
\end{tabular}

To be able to analyse the acquisition of negative forms in the child's speech, three sets of data were transcribed. The forms of negation in Turkish are presented in details in the second section. Table 2 shows that the child could produce 381 utterances out of $1140(33 \%)$ at the age of $1 ; 8$. This slightly increases at the age of 1;9, up to 494 utterances out of 1350 (36\%). Finally, there is a dramatic rise in the child speech at the age of $1 ; 10(75 \%)$. This reveals that the child manages to produce three quarters of the conversation in the last data set.

Table 3. The percentage of child negative utterance

\begin{tabular}{ccccc}
\hline Sets & Age & $\begin{array}{c}\text { Child Total } \\
\text { Utterance }\end{array}$ & Child Negative Utterance & Percent \\
\hline Set 1 & $1 ; 8$ & 381 & 15 & $4 \%$ \\
Set 2 & $1 ; 9$ & 494 & 28 & $6 \%$ \\
Set 3 & $1 ; 10$ & 676 & 59 & $9 \%$ \\
\hline
\end{tabular}

In table 3, there are 15 negative utterances out of 381 in the first set, and it gradually rises from $4 \%$ to $6 \%$ in the second set ( 28 negative utterances out of 494 ). In the third data set, the child produces 59 utterances with negation out of 676 with a $3 \%$ increase in the use of negation.

Table 4. Negative Elements in the Child's Turkish according to age intervals

\begin{tabular}{cccccccc}
\hline Age & $\begin{array}{c}\text { lh hıh } \\
\text { /clk }\end{array}$ & değil & Yok/ yoo & -mA & hayır & no & Total \\
\hline $1 ; 8$ & 13 & 0 & 1 & 0 & 1 & 0 & 15 \\
$1 ; 9$ & 26 & 0 & 1 & 0 & 1 & 0 & 28 \\
$1 ; 10$ & 17 & 2 & 17 & 19 & 6 & 1 & 61 \\
\hline
\end{tabular}

As mentioned in the previous sections, there are various ways of forming negation in Turkish. These are $\imath h h l h$ (also $c l k$ in one case) (vocal negative response), değil (negation for mainly nominal sentences), 
yok (yoo in some cases) (non-existent) as the negated form of var (existent), - $m A$ for verbal sentences. The child uses haylr to give negative response to some questions. While yok is commonly used as the negative response in colloquial speech, hayır is a more neutral word. However, the intended meaning is identical. The child also uses English word ' $n o$ ' to make negatives. It can be the effect of rich input in English in the house. Table 4 shows the use of the six different ways of making negation in each set in numbers with the addition of the total records. While some forms allow for a freer use in different contexts, the use of some can strictly depends on the other components of the sentence. Namely, the sentence determines whether it is dependant or not, which has been taken into consideration in the analysis of the data in the following extracts.

\subsection{The Use of 'ih hih' (can be ahh, uh huh)}

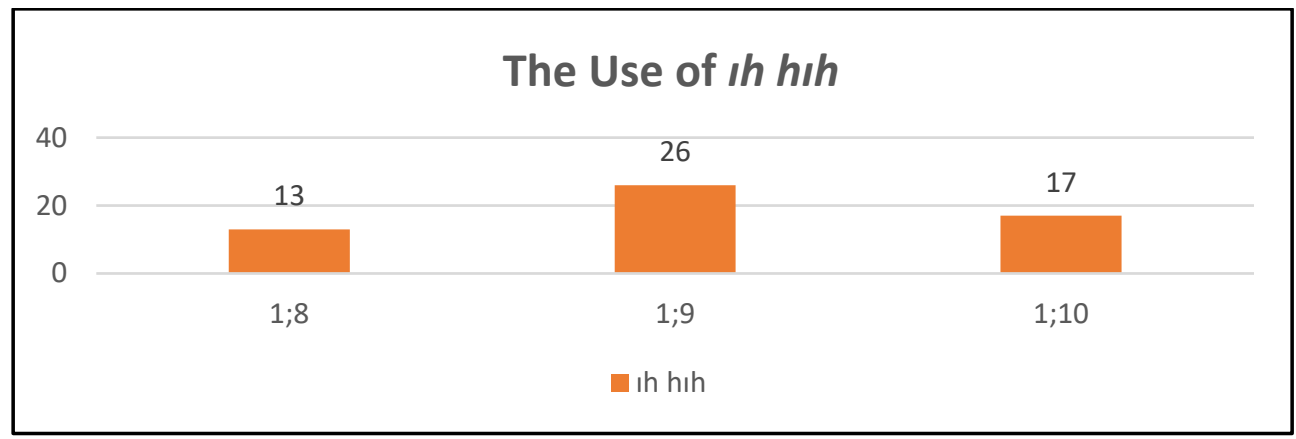

Chart 1: The use of $\iota h h t h$ according to age intervals

In the first data set, $\imath h \mathrm{~h} h \mathrm{~h}$ is used for 13 times in 15 negative utterances (86\%). At the age of 1;9, the percentage slightly increases up to $89 \%$, with 26 times out of 28 , but in the last data set, it dramatically drops to $24 \%$ as the child acquires other forms of negation. It can be assumed that he does not prefer to use vocal negative gestures very frequently. Rather, he uses the different means of negation at his service more strategically. It is revealed that he does not have to stick with the same structure while he has more variety, which can offer a more suitable option for his purpose. Another point is that child has not acquired negative utterances with other methods, so he uses this sound gesture to show her disagreement because the data shows that he uses $t h$ hih in other ways as illustrated in the example.

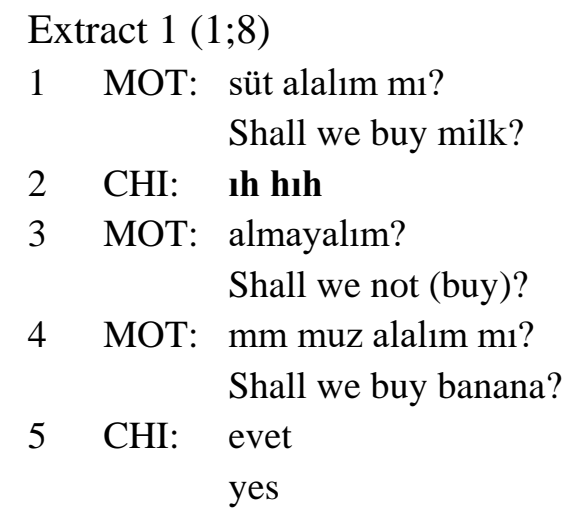

Extract 1 illustrates that the child can express his feelings even as early as 20 months old. This is one of the extracts taken from the beginning of the first data set and it clearly shows the child's rejection for his mother's offer in line 2 . He does not use $t h$ h $h$ continuously for any offer from his mother, line 5 evidences this well. It also proves his ability for comprehension. 
Extract $2(1 ; 9)$

1 MOT: olmuyor mu?

Does it not work?

2 CHI: ih hıh

no

3 MOT: olmuyor

It doesn't work

4 MOT: arabanınki oluyor mu?

Does the one on the car work?

5 CHI: evet

yes

The child overuses this vocal negation form to answer positive statements and questions as well as negative questions directed by his mother. In Extract 2, they try out the horn of a new car. It can be said that the child has not developed the competence to form a verbal sentence with $-m A$ at the age of $1 ; 9$, so $t h h t h$ is virtually the only method he uses to make negation.

Extract $3(1 ; 9)$

1 MOT: saklambaç oynayalım mı?

Shall we play hide-and-seek?

2 CHI: ih hih birak

NEG leave (me alone)

3 MOT: hani sen saklanıyordun ya anneanne bulamıordu seni

You hide and your mother can not find you

4 MOT: aşağıya gidelim

Shall we get down (to the garden)?

5 CHI: yukarı çık

Go up

In the last weeks of the second data set, he starts using other verbs with $\imath h \mathrm{~h} h \mathrm{~h}$ to accentuate his points. In Extract 3, the mother wants to play with him, but he strongly rejects the suggestion. He also continues to get his point across by stating the opposite of his mother's offer. In line 4, his mother suggests him to take him out to play in the garden, but he wants to go upstairs. He uses the verb in stem form, as he has not developed the production of volitional utterances yet, though he shows no difficulty in comprehension.

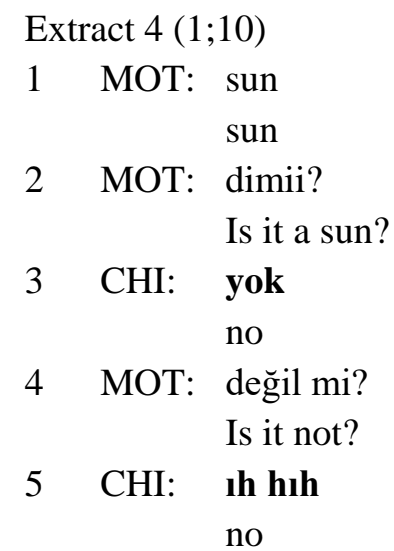


At the age of $1 ; 10$, he starts using $\imath h \mathrm{~h} h \mathrm{~h}$ as one of the ways to make negation, but he can produce negation in many different ways, so he mixes and matches them according to his needs. In Extract 4, the parent and the child have a dialogue about a picture of the Sun. The mum asks if it is the Sun and the child answers with yok, but the mother gets surprised and uses a negative question this time. Instead of using the same form of negation, the child replies with $t h \mathrm{~h} t h$ as shown in line 5. This indicates that as he becomes more competent in making negations, he uses the structures more strategically.

\subsection{The Use of 'değil'}

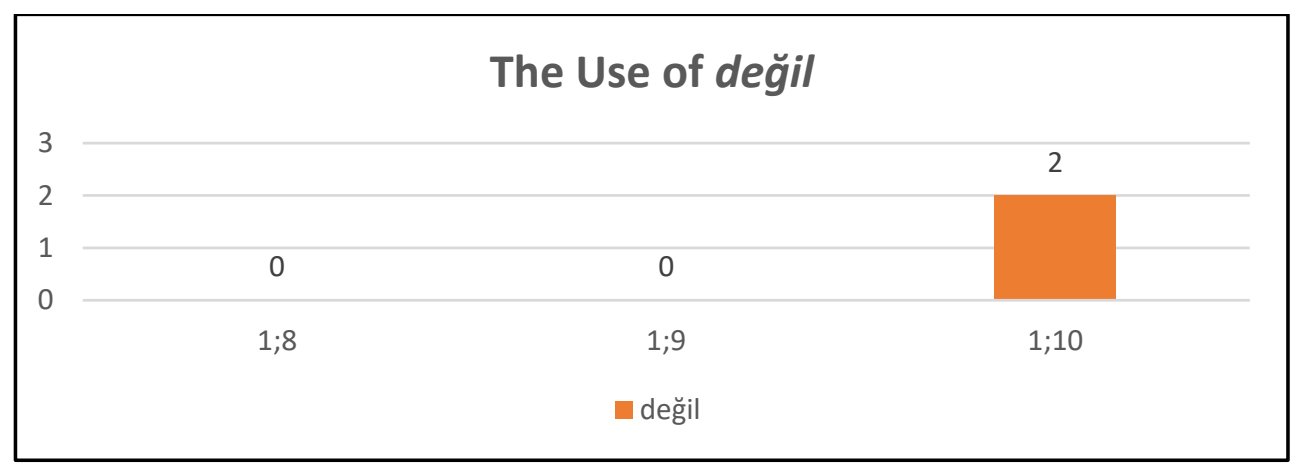

Chart 2: The use of değil according to age intervals

This child never uses değil to form negation in the first and second data sets $(1 ; 8,1 ; 9)$. The data shows that there is input from his mother, but he never produces it. He generally uses $t h$ hih in the first and second data sets. In the last set, he uses it only twice (3\%). He recognises the word değil at the comprehension level since he has not been at the production level yet. Therefore, he generally prefers the structures he is more familiar with or the ones he has practiced before, which cause less misunderstanding in his communication.

Extract $5(1 ; 10)$

MOT: pencere mi?

Is it a window?

CHI: değil

No (it isn't)

MOT: değil

No (it isn't)

In Extract 5, he is aware that the word değil is used for nominal sentences. Because his mother uses değil typically as a tag question, he might think that it is not an utterance that adds negation to the sentence. Rather, it is used in questions to seek confirmation for the statement. Değil mi? is a combination of the negative particle değil 'not' and $m I$, and is often pronounced as ([di:mi ] or [ dimi]) in informal registers. Questions with değil mi are unmarked tag questions similar to 'isn't it', 'can you', etc. in English. This question type is used when the speaker looks for validation or conformation of a statement that she/he believes to be true.

Extract $6(1 ; 10)$

MOT: giderken dönüyor dimi? (değil mi?)

It rolls as it goes, doesn't it?

MOT: gece oluyor dimi? (değil mi?)

The night falls, doesn't it? 


\section{MOT: önünden çekiyim demi (değil mi)?}

I shall pull it from the front, won't I?

As it is clear from Extract 6, the mother uses değil mi? in questions to get confirmation or seek the child's agreement. It is mostly pronounced in weak form as it is unmarked in the sentence. Moreover, it does not change the meaning of the sentence substantially compared to other structures of negation. The child uses it twice to negate a nominal sentence correctly, but not as a tag question. Keeping this in mind, it can be even more challenging to separate this function of değil from its negating one. The child never uses it in its weak form ([di:mi ], [dimi] or [demi]), which provides an important clue about the simple division he makes between these two functions.

\subsection{The Use of 'yok'}

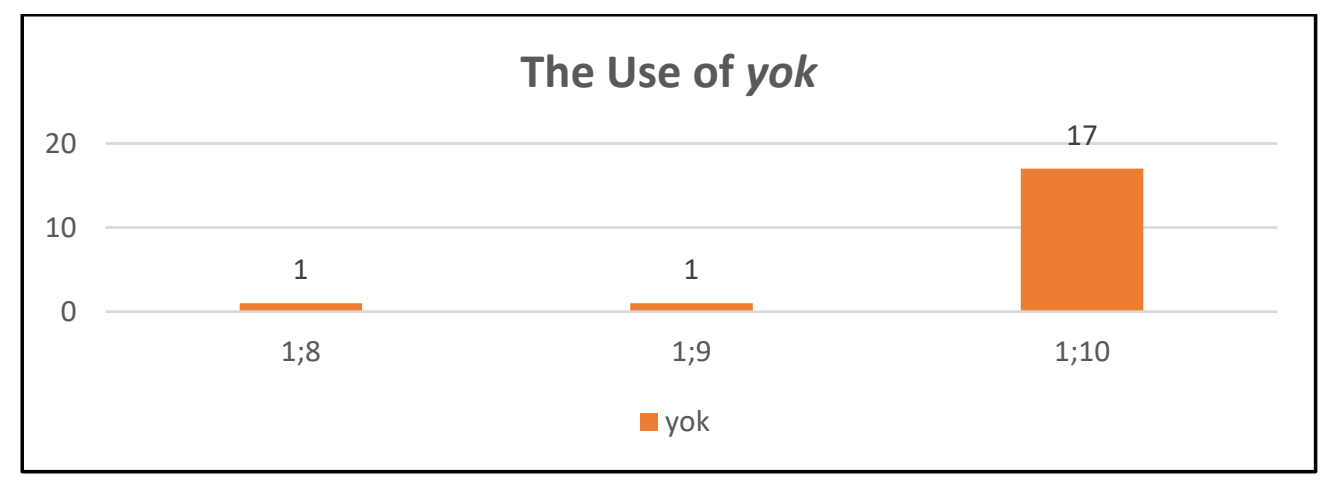

Chart 3: The use of yok according to age intervals

The data shows that he uses yok only once in the first $(1 ; 8)$ and second data sets $(1 ; 9)$. At the age of $1 ; 10$, his use of yok significantly increases from $3 \%$ to $29 \%$. It can be traced from the data the way the child uses yok expands. It develops gradually as he practices using it as a complete answer as well as providing more details in his longer answers such as explaining reasons and results of why something or somebody is non-existent.

Extract $7(1 ; 8)$

1 MOT: düt dütü yok muymuş?

2 CHI: yok

Extract 7 shows that the child uses yok only once in the first data set. In this example, the question directed to the child is also in negation, so it is hard to say that he has acquired the form of negation with yok because the negative inflected utterances can easily be imitated by the child.

Extract $8(1 ; 9)$

1 MOT: Yusuf Ata nın terliği var mı?

Does Yusuf Ata have slippers?

2 CHI: yok

No (not existent)

3 MOT: ne giyiyor Yusuf Ata?

What does Yusuf Ata wear?

4 CHI: aak ka

5 CHI: ayapka (ayakkabı)

shoes 
However, in Extract 8, he proves that he has acquired this form at the age of 1;9. He manages to answer the question asking about the existence of slippers successfully and justifies his answer in line 4 and 5. In this data set, he uses it only once, but the usage is correct.

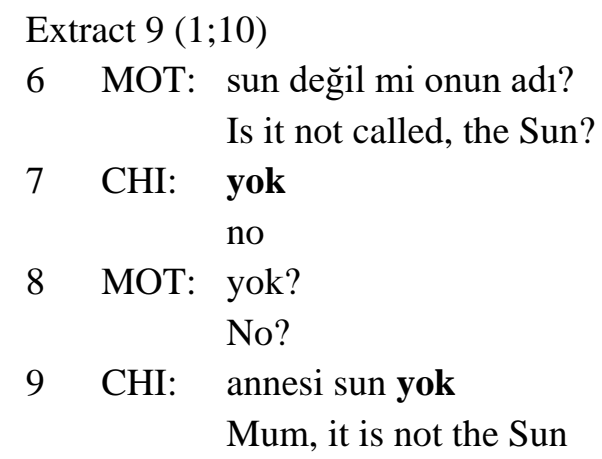

In the last data set, he uses yok for 17 times. Extract 9 evidences that he does not only produces yok as a full answer to a question. Moreover, he uses other components to support yok such as telling what is not existent and who the addressee of the sentence is. This is a clear example of his development of the forms of yok.

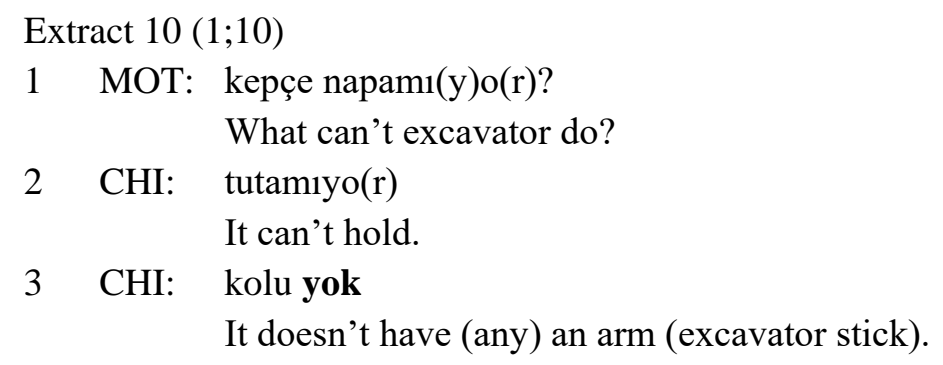

In Extract 9, the child uses $-m A$ first in line 2 and then yok and what is not existent to make his point clearer and stronger. Also, we can say that he gives the reason of the first negated utterance tutamiyo(r) in the second negated one (because) 'it doesn't have an arm' (or excavator stick). Moreover, this shows that one way of forming negation does not prevent another to be used. "Repeating the negativity, but not the same form of negative, is a linguistic device children start to use as a way of stressing their point of what the adult suggests, requests or asks" (Al-Buainain, 2003). This type of negation is formed by yok plus the negative morpheme -mA. The ability to form all these brings richness and variety to the speech of the child.

\subsection{The Use of '- $m A$ '}

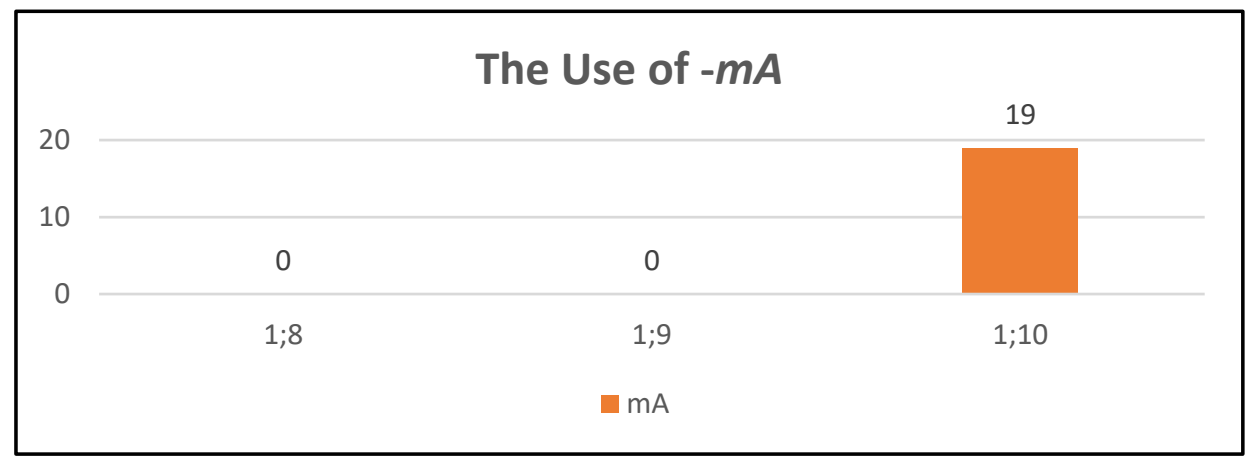

Chart 4: The use of $-m A$ according to age intervals 
The use of $-m A$ is not available in the first two data sets and it suddenly increases at the age of $1 ; 10$ and the child uses it for 19 times in his interactions (32\%). This proves that he has acquired the negation in verbal sentences at about 22 months. He also can inflect the verbs successfully for negation such as olMUyo(r), yeME, çıkaraMIyorum, görMÜyor, çıkaraMAyacă̆ım.

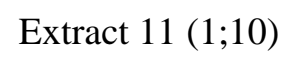

1 CHI: çık-a-mı-yo (r)

Go up ABIL NEG PROG 3SG

2 CHI: beyaz araba çık-a-mı-yo (r) white car Go up ABIL NEG PROG 3SG

Here the child's process of development is evident. The child produces the verb first, and then, he scaffolds the subject, the object or the rest upon the verb. He completes a missing component in his sentence. This lightens the burden of making a complete comprehensive sentence at the first attempt, so he produces one item at each attempt. Thus, we can say that the development goes from the general to the more specific. For example, in Extract 11, the child initially produces the verb, and then, he remakes the sentence with the addition of the subject.

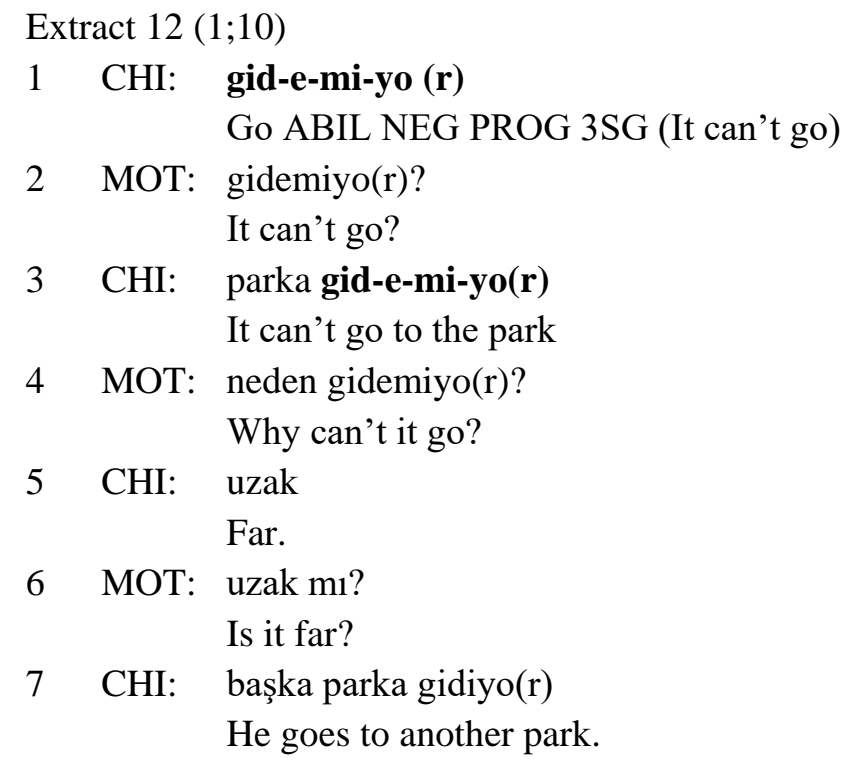

The initial use of verb and associating it with another semantic element are repeated several times in the last data, which shows that the child has acquired the structure successfully. He follows the pattern of producing one element at a time in each example. In Extract 12, he produces the verb first again and in line 3, he adds the adverb of place 'to the park' to make the meaning clearer. Then, his mother asks him why the car cannot go to the park, he clarifies that the park is 'far'. Therefore, he produces a meaningful explanation. The statement is complemented with the subject later as in 'the car goes to another park'. He also chooses the suitable tense for the context, which is the Present Continuous, as a response to the question in the same tense.

Extract $13(1 ; 10)$

1 MOT: Fata ayağını çıkarıyor

Fata takes off his foot (socks)

2 CHI: çıaramıyom (çıkar-a-mı-yor-um) take off ABIL NEG PRE CONT 1SG

I can't take (them) off 
3 CHI: ayağ-ım-a (ayağımdan) çıkaramıyom

Foot POSS DAT Take off ABIL NEG PROG 1SG

I can't take (them) off my foot

4 CHI: hop çıkardım (he takes off one of his socks)

upps I have taken them off

5 MOT: çıkardımm

I have taken them off

6 CHI: çıarcam

I will take them off

7 MOT: çıkarıyor musun?

Will you take them off?

8 CHI: hopp (vocal gesture such as upps in English)

9 CHI: çıaramicam (çıkar-a-ma-yacağ-1m)

Take off ABIL NEG FUT 1SG

I can't take (them) off.

At the age of $1 ; 10$, the child uses $-m A$ competently to maintain the conversation. In Extract 13, he tries to take off his socks without his mother's help. He uses the same verb ç1kar- 'take off' many times in his turns. He takes the one off in line 5 and tries to remove the other one. In line 7, his mother asks him if he is taking off in the Present Continuous Tense, but the reply comes in the Future tense, showing that he is going to give up trying.

In this data set, there are a number of variety sets in which the child uses the negative form of the same verb in different tenses. It shows that he is capable of forming the verb for both positive and negative sentences in various tenses. He produces 4 distinct forms of the same verb in different tenses:

$\begin{array}{lll}\text { çıkaramıyom } & \text { (çıkar-a-mı-yor-um) } & \text { take off ABIL NEG PROG 1SG } \\ \text { çıardım } & \text { (çıkar-dı-m) } & \text { take off PAST 1SG } \\ \text { çıarcam } & \text { (çıkar-acă̆-1m) } & \text { take off FUT 1SG } \\ \text { çıkaramicam } & \text { (çıkar-a-ma-yacağ-1m) } & \text { take off ABIL NEG FUT 1SG }\end{array}$

Furthermore, the negated verbs are generally used with the negative forms to express his physical (in)ability in the speech as well. He uses the negative form of ability with action verbs repeatedly in the following ways:

\begin{tabular}{|c|c|c|}
\hline Çıkaramıyom & (çıkar-a-mı-yor-um) & take off ABIL NEG PROG 1SG \\
\hline çıkaramicam & (çıkar-a-ma-yacağ-1m) & take off ABIL NEG FUT 1 SG \\
\hline çıkamıyor & (çık-a-mı-yor) & go up ABIL NEG PROG 3SG \\
\hline Yapamiyom & (yap-a-m1-yor-um) & do ABIL NEG PROG 1SG \\
\hline Gidemiyo & (gid-e-mi-yor) & go ABIL NEG PROG 3SG \\
\hline Tutamiyo & (tut-a-m1-yor) & hold ABIL NEG PROG 3SG \\
\hline
\end{tabular}

There are also verbs in negative forms that are in the Present Continuous Tense in form, but their functions and meanings express (in)ability again. The child signals his willingness to do an activity, but he cannot do it because he is not mentally or physically capable of doing it yet. Another point is that in the beginning of the data, he starts to use $-m A$ in verbal sentences without a personal marker, the subject of the sentence. It seems that $3 \mathrm{rd}$ person singular subject is used instead of the $1^{\text {st }}$ person singular subject. However, it would be wrong to say that the child is aware of personal markers, so he uses $3^{\text {rd }}$ person singular instead of $1^{\text {st }} .3^{\text {rd }}$ person singular takes no markers in the verb. Thus, it can be assumed that the 
child uses no personal marker yet because he can not produce it yet. The following examples illustrate the case.
olmuyo
(ol-mu-yor)
happen NEG PROG 3SG
(I can't do (it))
durmuyo
(dur-mu-yor)
stop NEG PROG 3SG
(I can't stop)
görmüyo
(gör-mü-yor)
see NEG PROG 3SG
(I can't see)

4.5. The Use of 'hayır'

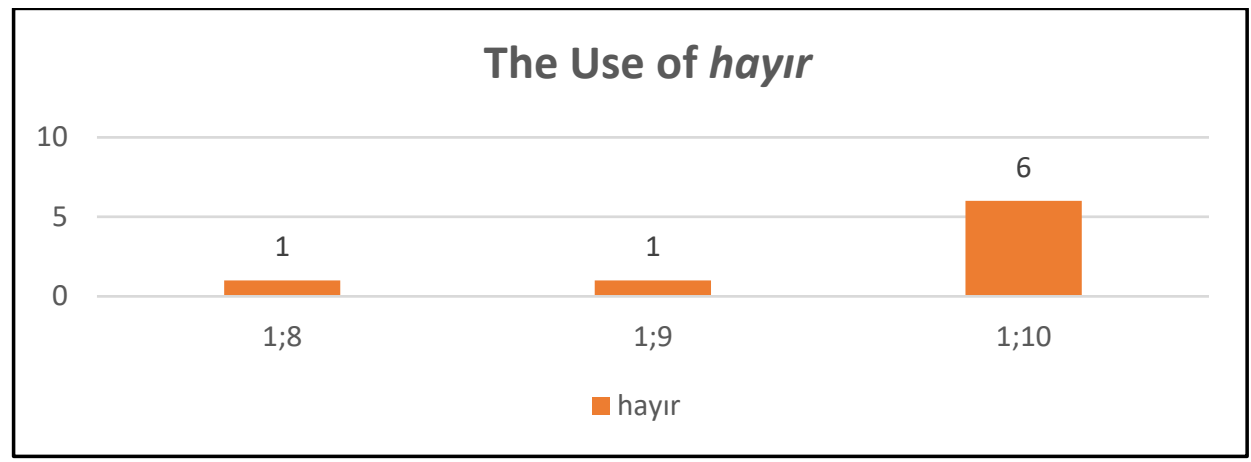

Chart 5: The use of hayır according to age intervals

The child uses haylr only once in the first two data sets. In the last one, it moderately increases up to 6 uses (10\%). Although the child uses it as an alternative, he does not prefer it as often as the other ways of forming negation (-mA, yok and $\imath h \mathrm{~h} h$ ).

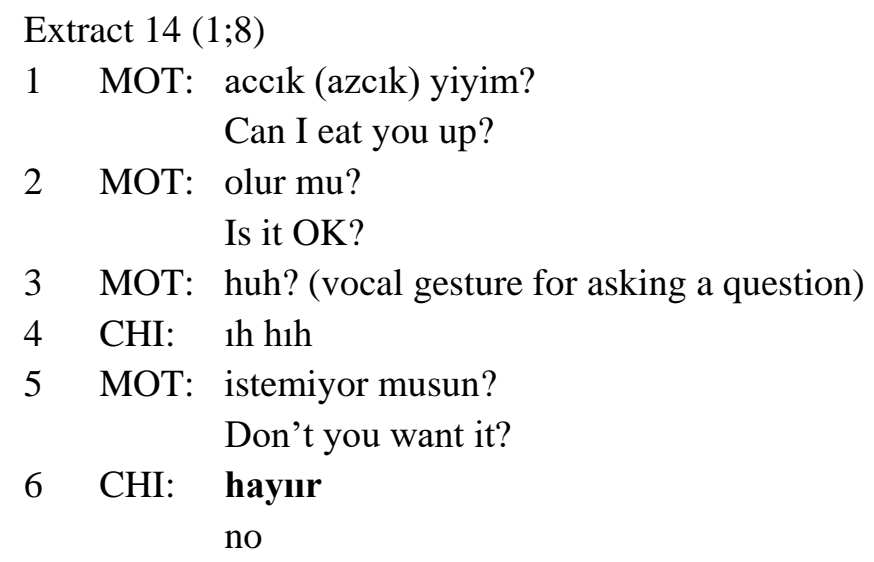

In Extract 14, the mother wants to eat up the child and asks for permission in the first three lines. In line 5 , he refuses it with the vocal negative $t h h l h$, but his mother tries to persuade him. This time he replies with haylr. Although there are not adequate examples of hayır in the data, it can be assumed that he uses hayır when he wants to reject an action or offer determinedly or put an emphasis on his decisive refusal. The child thinks that haylr will be a more effective utterance than $t h$ hih for refusal in this case.

Extract $15(1 ; 9)$

1 MOT: simit almadinız mı?

Did you not buy pastry?

2 CHI: geldi

we came

3 MOT: evet simit almaya gitmediniz mi?

Ok did you not go to buy pastry? 


\section{CHI: hayır geldi}

No, we came

Intended meaning: No, we didn't go (because) we have come, we are here now.

At the age of 1;9, the child uses hayır with explanation. In Extract 15, the mother asks if they have gone to buy pastry, but the child does not comprehend the question. He produces the verb first and then, his mother repeats the question and this time she elucidates by giving the stages of buying pastry (go and then buy pastry). However, the child repeats his answer geldi( $k$ ) (we came) by adding the negative word hayır before it. Furthermore, he knows that he needs to give an explanation when he produces a negative statement. This is one of his early attempts to use hayrr, so we can say that he does not only work on the form of the negation, but also tries to comprehend the pragmatic and semantic use of the forms.

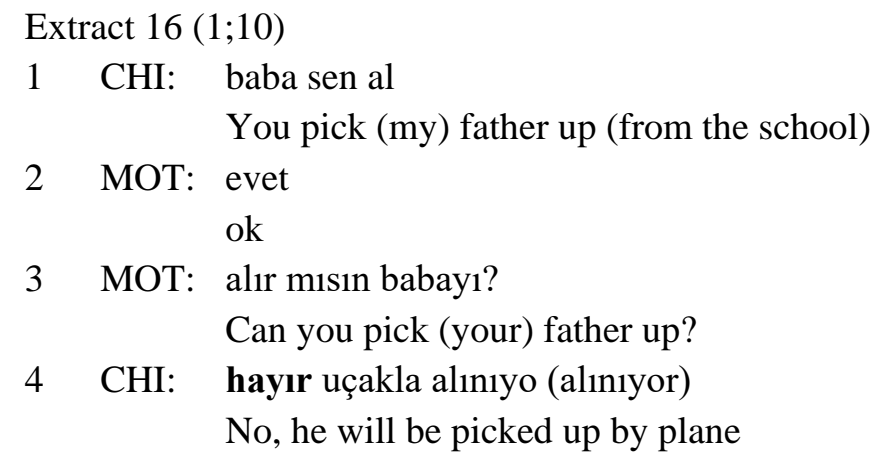

In the last data set, the child and the mother talk about picking up his father from the school. The child drives a toy car and the mother asks him to collect his father by his toy car in line 3. He replies negatively with an explanation of why he says so. This example is important as the child starts using the passive voice for the first time in the recordings.

4.6. The Use of 'no'

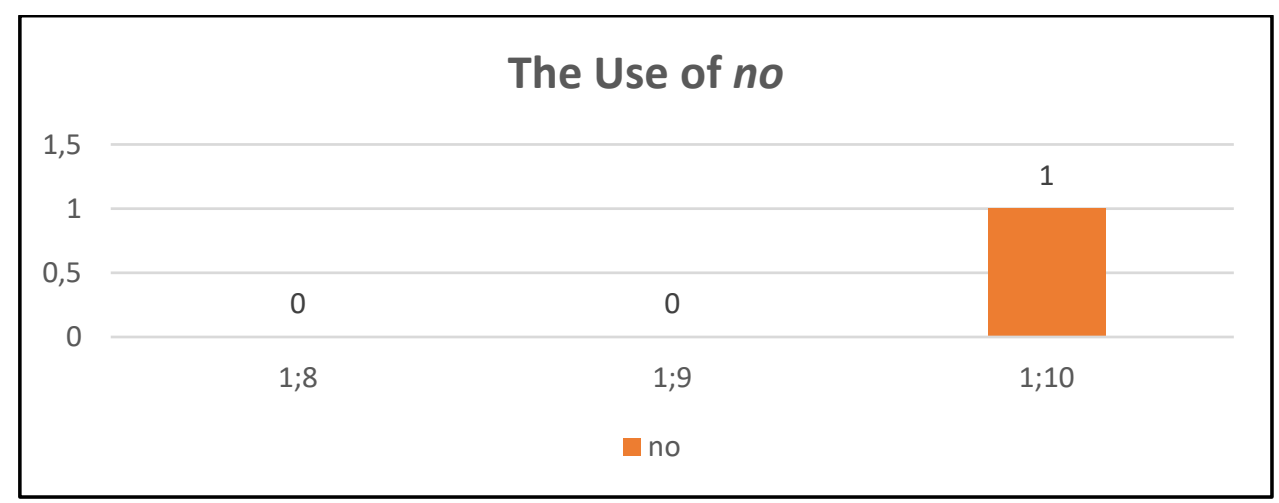

Chart 6: The use of no according to age intervals

The child starts using English word ' $n o$ ' at home at the age of 1;10 after a prolonged exposure to English. He might have heard it from the videos he has watched or from his parents who often speak English with him. The English word 'no' is only used once, but it is used correctly in the accurate context, which indicates his growing competency in differentiating the words from another language. 
Extract $17(1 ; 10)$

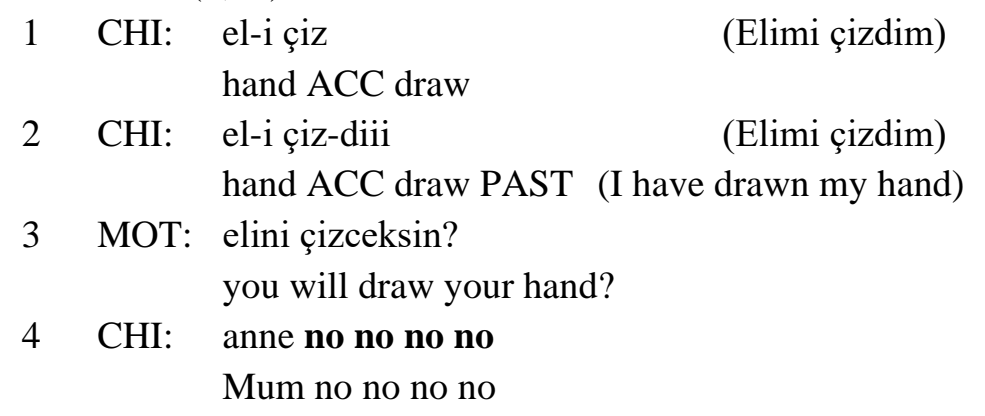

In Extract 17, we can see the child processing the language slowly in the each turn to be understood by his mother. In line 1, he tells his mum that he has drawn a picture of his hand on the paper. As the mother cannot notice it on the paper, she misunderstands him. In line 4, the child replies directly and automatically using 'no' and he repeats it four times in the same turn. He might have used 'no' mechanically; in other words, as a vocal expression such as yoo (yok meaning 'no' in colloquial speech) in Turkish. Additionally, the dad uses 'no' in repetition in his speech, thus it can be the reflection of input by his father.

\subsection{Negative Question}

Forming negative questions can be challenging, so they are typically acquired at a later stage (AlBuainain, 2003). However, Turkish children begin to use negative questions at very early ages even though they can be semantically and functionally problematic. In Turkish, to form yes/no and alternative questions, the question particle $-m I$ is inserted; and as for wh-questions, $w h$-phrases are used such as $n e$ zaman 'when', kim 'who' or neden 'why'. Children only add - $m I$ to the end of the verb by inflecting the suffix. In these questions, the child is aware that by only adding the wh- question word before the verb, he can make questions in Turkish. There are no negative yes/ no questions in the data, which can be challenging and confusing for the child to use. The question word neden is one of the question words that is acquired later compared to other wh- questions. However, because the mother directs this question a lot in her speech (Data set 1: 5, Data Set 2: 4 and Data Set 3: 20 times), this child starts to use it with a negative question at the age of $1 ; 10$ as sampled in Extract 18 .

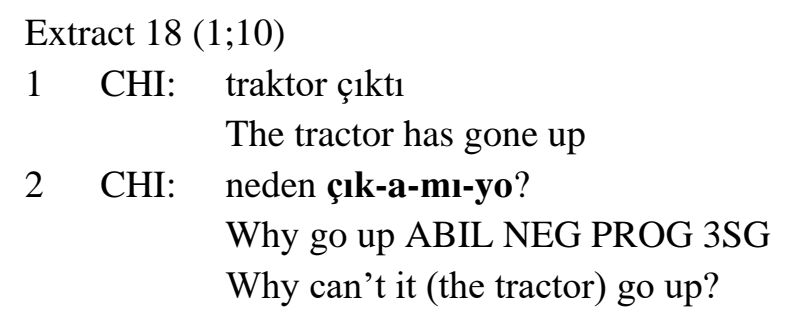

\section{Conclusion}

The development and variations of negation by a Turkish child have been described and interpreted in this paper. The analysis has showed that the development of forms and their functions of negation in parent-child interactions start at the very early stages of language acquisition. The data provides considerable insight into the development of negation in Turkish. In other words, the child acquires the forms of negation in a clear developmental sequence and this reveals that he expands his use of negation in each set of data. To illustrate, the child starts using yok as an independent predicament and later he connects it with other complements by reasoning such as 'tutamıyo(r) (çünkü) kolu yok (it can't hold (because) it doesn't have an arm (excavator stick)' (Extract 10). Therefore, he uses the word yok, but he 
expands on its functions and usage each time. Each negative forms is used in harmony with the context. Even though the child knows how to make negative form of a verb with $-m A$, he still uses the others to support his point or to show his opinion in a stronger way.

As he practices the forms that he has learned previously, he elaborates on it by complementing with another item. When he comprehends and then begins to produce a new negative linguistic form, the use of particular forms changes gradually (İnci Kavak, 2018). In other words, the children's utterances reflect a pattern of increasing complexity. Complexification involves the substitution of general rules and replacing them with the more specific ones in different contexts The previous research has established that Turkish children acquire nearly all of the verbal paradigm before 2 years old (Aksu-Koc $\&$ Slobin, 1985). The data supports this claim because when the child is recorded at the age of 19 months and he could only use $i h h i h$ to form negation. He continued to use $\imath h$ hih in the second data set, too. However, at the age of 22 months, the child suddenly starts to employ different negative words and forms correctly. As he grows up, his production gains not only semantic and syntactical complexity but also rich variety.

The data bears various aspects of acquisition that interact with each other in the development of negation. These are the development of word order, which is about placing a word in the appropriate position in relation to the verb; the development of tense, which is about the ability to realize negative particles as tense carriers; the development of inflection, which is about the ability to express number, gender, person and tense. They all feed into the development of negation in the child's speech as early as the age of 2. This includes the comprehension of the correct form of the negative particle (for sentence type) and its assignment to an appropriate position to collaborate with or transform the verb (action) to convey different meanings, reject suggestions and offers, show refusals, provide reasons and explanations as well as emphasising a point by the child.

\section{References}

Abdulkarim, L. and Roeper T. (1998). Semantics or Syntax for Negative Islands in Language Acquisition. In The Proceedings of the 22nd Annual Boston University Conference on Language Development (Vol. 1, pp. 39-49).

Aksu-Koc, A. \& Slobin, D. I. (1985). The acquisition of Turkish. In D. I. Slobin, (ed.) The crosslinguistic study of language acquisition. Vol. 1. The data. Hillsadle, NJ: Erlbaum.

Al-Buainain, H. (2003). Developmental Stages of the Acquisition of Negation and Interrogation by Children Native Speakers of Qatari Dialect, Journal of the Faculty of Humanities and Social Sciences. (25), 9-45.

Bellugi, U. (1967). The acquisition of negation. Doctoral dissertation. Harvard University.

Bloom, L. M. (1970). Language development: form and function in emerging grammars. Cambridge, MA: M.I.T. Press.

Capdevila i Batet, M., Llinàs i Grau, M. (1995). The Acquisition of Negation in English. Atlantis, 17(1-2), 27-44.

de Villiers, P. A. \& de Villiers, J. G. (1979). Form and function in the development of sentence negation. Papers and Reports of Child Language Development. (17), 57-64. 
Fernald, A. (1993). Approval and Disapproval: Infant Responsiveness to Vocal Affect in Familiar and Unfamiliar Languages. Child Development. (64), 657-674.

Erguvanl1, E. (1979), An Odd Case in the Causative Construction of Turkish. In Papers from the Fifteenth Regional Meeting of the Chicago Linguistic Society. Chicago Linguistic Society, Chicago.

Göksel, A. \& Kerslake, C. (2005). Turkish: A Comprehensive Grammar, London: Routledge.

Greenberg, J. H. (Ed.). (1966). Universals of language (2nd ed). Oxford, England: M.I.T. Press.

Horn, L. R. (1989). A natural history of negation. Chicago: The University of Chicago Press.

İnci Kavak, V.(2018). The Development of Forms of Negation in the Acquisition of Turkish. Journal of Language and Linguistic Studies, 14(4), 93-110.

Klima, E. S. \& Bellugi, U. (1966). Syntactic regularities in the speech of children. In J. Lyons\& R. J. Wales (eds). Psycholinguistic papers. Edinburgh: Edinburgh University Press.

Krashen, S. (1981). Second language Acquisition and Second language Learning. Pergamon Press, Oxford.

Küntay, A., \& Slobin, D. I. (2002). Putting interaction back into child language: Examples from Turkish. Psychology of Language and Communication. (6), 5-14.

Lehmann, H. (1978). H. Interpretation of Natural Language in an Information System. IBM Journal of research and development. 22(5), 560-572.

McNeill, D. and McNeill, N. B. (1995). What does a child mean when he says no. T Charles A. Ferguson and Dan 1. Slobin, (eds.). Atlantis, 17 (1-2), $27-44$.

MacWhinney, B. (1976). Hungarian Research on the acquisition of Morphology and Syntax, Journal of Child Language. (3), 397-410.

Slobin, D. I. (1986). The Acquisition \& Use of Relative Clauses in Turkic \& Indo-European Languages. In Slobin, D. I. \& Zimmer, K. (eds) Studies in Turkish Linguistics, Amsterdam: John Benjamins Publishing Company.

Underhill, R. (1976). Turkish grammar. Cambridge, Mass: M.I.T. Press.

Vaidyanathan, R. (1991). Development of forms and functions of negation in the early stages of language acquisition: a study in Tamil. Journal of Child Language, (18), 51-66.

Wode, H. (1976). Four early stages in the development of L1 negation. Journal of Child Language. (4), 87. 


\section{Çocuk dilinde olumsuz ifadelerin edinimi ve kullanımı}

\section{$\ddot{O} \mathbf{z}$}

$\mathrm{Bu}$ çalışma, ana dili Türkçe olan bir çocuğun konuşma dilinin aşamalarında olumsuzluğun nasıl geliştiğini araştırmaktadır. Çalışma, bir çocuğun 19-22 ayları arasında video kayıtlarını ve kaydedilen verilerdeki negatif formların analizini içermektedir. Ebeveyn-çocuk etkileşimlerindeki olumsuzluk ifadelerinin gelişimi, çocuk ve ebeveynler arasındaki örneklerle tartışılmaktadır. Veriler, özellikle oyun ve öğle yemeği saatlerinde, anne tarafından düzenli bir şekilde kaydedildi. Kayıtlar, detaylı veri analizi için çocuğun yaşına göre $1 ; 8,1 ; 9$ ve 1;10 olmak üzere üç gruba ayrılmıştır. İlk adım, Türkçe'de olumsuzluğun nasıl oluştuğunu tanımlamak ve açıklamaktır; bunu, çocuğun konuşmasında olumsuzluk gelişimini takip etmek için kullanılan veri analizi izler. Çocuğun dil bilgisi genişledikçe, olumsuzluk ifadelerinin gelişme şekilleri özel bir ilgi gösterilmiş ve yorumlanmıştır. Veriler, çocuğun 1;10 ay gibi erken bir yaşta bile çoğu olumsuzluk türünü kullanmaya başladığını, aynı zamanda bunları başarılı bir iletişim için, net bir gelişim sırasında ve stratejik olarak gerçekleştirdiğini kanıtlar. Verilerde bulunan stratejilerinden bazıları, çeşitli kümeler, fikrini güçlendirmek için, bir olumsuz ifadeyi diğeriyle tamamlama ve sebep ve sonuç belirtmedir. Elde edilen bulgular, çocuğun olumsuz ifadeleri, bağımsızdan daha bağımlıya ve aynı zamanda kolay ve dilbilimsel ve bilişsel olarak kolaydan daha zor olana doğru bir sırayı takip ettiğini doğrulamaktadır.

Anahtar sözcükler: Çocuk dili; Türkçe dil edinimi; olumsuz ifadeler; olumsuzluk gelişimi

\section{AUTHOR BIODATA}

Vildan INCI KAVAK works as an instructor in the School of Foreign Languages at Gaziantep University. She received her BA and MA degrees in English Language Teaching from Muğla Sitkı Koçman University and she continues her PhD in ELT at Çukurova University. She is also a holder of Cambridge DELTA, which she received from Leeds Metropolitan (Beckett) University, England. Among her research interests are Conversation Analysis, teacher professional development, first \& second language acquisition and teaching English to young learners. 